\title{
PEMANFAATAN LIMBAH PLASTIK MENJADI PRODUK INDUSTRI KREATIF DI SMP NEGERI 1 KAMANG MAGEK KABUPATEN AGAM PROPINSI SUMATERA BARAT
}

\author{
Yunis Muler1), Rajudin²) \\ 1)2)Program Studi Seni Murni, Fakultas Seni Rupa dan Desain, Institut Seni Indonesia Padangpanjang \\ Jl. Bahder Johan Padangpanjang Kodepos 27128 \\ Email : yunismulersenimurni@gmail.com ${ }^{11}$, sirajudinsiraj@gmail.com ${ }^{2 j}$
}

\begin{abstract}
ABSTRAK
Sampah kaleng plastik merupakan sampah jenis anorganik yang banyak ditemukan di sekitar kita. Sampah ini sangat sulit terurai walaupun dalam jangka waktu yang sangat lama. Sampah kaleng plastik dapat menimbulkan dampak negatif bagi kelestarian lingkungan hidup. Berdasarkan data yang dirilis oleh The Economist pada 3 Maret 2018; 6,3 miliar ton sampah plastik telah diproduksi di seluruh dunia sejak tahun 1950. Berdasarkan fakta tersebut, perlu usaha kreatif untuk sedikit mengurangi kuantitas sampah plastik. Pelatihan ini adalah salah satu usaha untuk sedikit mengurangi kuantitas sampah plastik di lingkungan dengan cara memanfaatkannya menjadi produk bernilai guna dan dapat dijadikan sebagai komoditas industri kreatif. Pelatihan ini telah diberikan kepada siswa dan siswi SMP Negeri 1 Kamang Magek sebanyak 15 orang. Pelatihan bertujuan untuk mendidik generasi muda yang kreatif, inovatif, kompetitif dan peduli terhadap lingkungan. Pelatihan ini menghasilkan beberapa produk industri kreatif seperti lampion, lampu tidur dan pot bunga. Beberapa produk yang telah dihasilkan dapat dijadikan sebagai stimulus/ perangsang, dan nantinya dapat dikembangkan sendiri oleh peserta pelatihan sebagai produk yang orisinal dan variatif, dan dapat dijadikan sebagai produk andalan untuk membuka peluang usaha dalam sektor industri kreatif.
\end{abstract}

Kata kunci : Limbah, plastik, produk, industri, kreatif

\section{PENDAHULUAN}

SMP Negeri 1 Kamang Magek adalah salah satu SMP Negeri yang terletak di daerah Kamang Hilia, Kecamatan Kamang Magek, Kabupaten Agam Provinsi Sumatera Barat. Sekolah ini dipimpin oleh kepala Sekolah bernama Andri. SMP 1 Kamang Magek memiliki 21 orang guru dan 5 orang tenaga kependidikan. Pada semester ganjil 2019/2020, SMP 1 Kamang Magek menyelenggarakan tiga rombongan belajar, yaitu rombel 7 dengan jumlah 42 siswa, rombel 8 dengan jumlah 39 siswa, dan rombel 9 dengan jumlah 39 siswa. Pada kesempatan pelatihan ini, siswa dan siswi yang diikutkan adalah siswa-siswa yang berada pada rombel 8 dipilih sebanyak 15 orang siswa. 15 orang siswa-siswi tersebut dipilih berdasarkan minat dan keinginan mereka terhadap materi pelatihan yang akan diberikan.

Permasalah yang dihadapai berawal dari keresahan bersama tentang sampah plastik. Keberadaan sampah plastik selalu menjadi masalah utama yang mengancam kelestarian lingkungan hidup. Sampah plastik merupakan sampah yang tergolong kepada jenis sampah anorganik, yaitu sampah yang tidak mudah membusuk dan sangat sulit terurai. Akumulasi dari sampah plastik yang ada di lingkungan akan berdampak buruk terhadap alam dan manusia. Sampah plastik dapat menimbulkan polusi. Polusi plastik dapat mencemari tanah, saluran air dan lautan. Organisme yang hidup di darat, sungai dan laut dapat terpapar oleh polusi sampah plastik. Paparan bahan kimia di dalam plastik dapat mengganggu fisiologi hewan dan manusia.

Pada tahun 2018, The Economist telah merilis, The 6.3bn tonnes of plastic waste produced since the 1950 s only $9 \%$ has been recycled and another $12 \%$ incinerated. The rest has been dumped in landfills or the natural environment (https://www.economist.com, diunduh pada Jumat, 29 Maret 2019, pukul 11.55 WIB). Hanya 9\% yang didaur-ulang, 12\% dibakar, dan lebih kurang sekitar 79\% sisanya dibuang ke tempat pembuangan sampah dan dibuang ke lingkungan alam. Fakta ini sangat mengejutkan. Sisa inilah yang menjadi masalah besar di berbagai negara di dunia, termasuk Indonesia. Isu strategis tentang ancaman akan berkurangnya tingkat kesuburan tanah merupakan isu yang 
sangat berkaitan langsung dengan sampah plastik. Hal ini dikarenakan bahwa sampah plastik sangat susah diuraikan oleh tanah meskipun sudah tertimbun bertahun-tahun. Sampah plastik baru bisa terurai oleh tanah setidaknya setelah tertimbun selama 200 hingga 400 tahun. Bahkan ada sebuah penelitian yang menyebutkan bahwa sampah plastik bisa terurai dalam waktu 1000 tahun lamanya. Karena proses terurainya sampah plastik yang membutuhkan waktu yang sangat lama, inilah yang kemudian mengakibatkan dampak sampah plastik buruk bagi lingkungan, seperti munculnya zat kimia yang dapat mencemari tanah, air tanah, dan juga makhluk yang hidup di bawah tanah. Racun-racun dari partikel plastik yang masuk ke dalam tanah akan berpotensi untuk membunuh hewan-hewan pengurai di dalam tanah, termasuk cacing. Selain itu, sampah plastik akan mengganggu jalur serapan air ke dalam tanah. Sampah plastik dapat menurunkan kesuburan tanah, karena sampah plastik dapat menghalangi sirkulasi udara di dalam tanah dan menghambat ruang gerak makhluk hidup bawah tanah yang berperan dalam proses penyuburan tanah (https://dosenbiologi.com/lingkungan/dampak-sampah-plastik).

Isu strategis lainnya yang berhubungan dengan masalah sampah plastik adalah isu tentang kelestarian hewan dan kesehatan manusia. Hewan-hewan dapat terjebak dalam tumpukan sampah plastik dan dapat menyebabkan kematian. Hewan-hewan laut seperti: lumba-lumba, penyu, dan anjing laut menganggap sampah plastik sebagai makanan, sehingga mereka akhirnya bisa mati karena memakannya dan tidak mampu mencernanya. Ketika hewan-hewan yang menelan sampah plastik mati, maka sampah plastik yang berada di dalam tubuhnya tersebut tidak akan hancur dan tetap utuh sehingga akhirnya akan menjadi bangkai yang dapat meracuni hewan lainnya, manusia yang berada di sekitarnya, hingga mencemari lingkungan dengan baunya yang biasanya busuk dan menyengat. Pembuangan sampah plastik secara sembarangan di sungai-sungai akan mengakibatkan pendangkalan sungai dan penyumbatan saluran, sehingga dapat menyebabkan banjir ketika musim hujan. Penyumbatan saluran air akibat sampah plastik dapat menjadi tempat perkembangbiakan daur hidup nyamuk dan serangga berbahaya lainnya, seperti nyamuk penyebab DBD dan malaria. Kualitas air di lingkungan akan semakin memburuk karena banyaknya sampah plastik yang mengandung bahanbahan kimia, seperti styrene trimer, bisphenol $A$ dan lain sebagainya. Bahan-bahan kimia ini akan meracuni air yang akan dijadikan air minum atau mandi sehari-hari. Isu tentang kesehatan manusia juga muncul akibat sampah yang dibakar. Isu ini muncul karena kebiasaan masyarakat yang mengatasi masalah sampah plastik dengan cara membakarya. Asap sampah plastik yang dibakar akan mencemari lingkungan. Asap tersebut mengandung zat dioksin yang apabila dihirup oleh manusia dapat menyebabkan berbagai gangguan kesehatan, seperti gangguan sistem pernapasan pada manusia, kanker, pembengkakan hati, dan gangguan sistem syaraf (https://dosenbiologi.com/lingkungan/dampak-sampah-plastik).

Berdasarkan permasalahan tersebut di atas, muncul sebuah keinginan untuk mengajak generasi muda, yaitu siswa-siswi SMP 1 Kamang Magek untuk sedikit peduli dengan realitas yang terjadi. Tujuan utama dari pelatihan ini adalah untuk menanamkan nilai-nilai kepedulian generasi muda terhadap lingkungannya. Keberlanjutan kelestarian alam merupakan tanggungjawab bersama dari individu-individu, dan harus ditanamkan sejak usia dini. Tujuan lain dari pelatihan ini adalah untuk memberikan pengetahuan dan keterampilan kepada generasi muda bahwa sampah plastik dapat dijadikan sebagai alternatif produk kreatif dan dapat dijadikan sebagai peluang usaha di era revolusi industri 4.0.

Pelatihan ini bermanfaat bagi siswa-siswi SMP 1 Kamang Magek dalam meningkatkan pengetahuan dan keterampilan dalam membuat produk industri kreatif dengan memanfaatkan sampah plastik. Perspektif mereka tentang sampah plastik jadi berubah, sampah plastik dapat membahayakan lingkungan alam, namun sampah plastik juga dapat dijadikan sebagai sebuah komoditi. Manfaat pelatihan ini terhadap lingkungan memang belum signifikan. Namun jika kesadaran dan kepedulian ini terus ditanamkan dan disebarluaskan kepada setiap generasi muda, sekolah-sekolah lain juga mengikuti hal yang sama, maka cita-cita untuk melestarikan bumi dan lingkungan hidup yang lebih sehat bukan tidak mungkin dapat diwujudkan.

\section{METODE PELAKSANAAN PENGABDIAN}

Kegiatan yang dilakukan adalah berupa pelatihan. Metode yang dilakukan dalam pelatihan ini yaitu menyiapkan alat dan bahan, membuat model produk, presentasi materi pelatihan serta teknik 
pembuatan produk, dan proses pembuatan produk. Berikut dijelaskan masing-masing dari metode pelatihan.

\subsection{Menyiapkan Alat dan Bahan}

Tahapan ini merupakan tahapan persiapan alat dan bahan yang digunakan untuk pelatihan. Alat yang disiapkan untuk pelatihan ini adalah sebagai berikut:

a. Ruangan kelas kapasitas 15 orang untuk tempat pelatihan.

b. Kertas HVS untuk membuat desain pola atau motif.

c. Pensil untuk membuat desain pola atau motif.

d. Pisau cutter untuk memotong pola atau motif.

e. Spidol permanen untuk menggambar pola pada pipa PVC.

f. Mesin gerinda tangan untuk memotong pipa PVC.

g. Mesin gerinda tangan mini untuk memotong pola atau motif pada pipa PVC.

h. Amplas untuk membersihkan sisa potongan pola atau motif.

i. Mesin hair dryer galon 1500 watt untuk melembekkan pipa PVC.

j. Solder listrik untuk melobangi pipa PVC.

k. Rol atau meteran untuk mengukur.

l. Pistol lem tembak untuk mencairkan lem lilin, digunakan untuk merekatkan fiber transparan pelapis pola atau motif pada pipa PVC.

m. Baskom plastik untuk mewarnai karya dengan teknik lukisan Ebru.

n. Obeng bunga untuk memasang skrup perangkat lampu pada pipa PVC.

Bahan yang disiapkan untuk pelatihan ini adalah sebagai berikut:

a. Pipa PVC bekas untuk bahan kap lampu.

b. Fiber transparan penutup pagar untuk bahan pelapis pola atau motif..

c. Cat semprot dan cat minyak kaleng untuk mewarnai lampion dan kap lampu.

d. Lampu 5 watt.

e. Kabel.

f. Cok dan fitting lampu.

g. Pilox clear untuk finishing lampion dan kap lampu.

\subsection{Membuat Model Produk.}

Tahapan selanjutnya adalah membuat model produk. Model produk yang diberikan sebagai acuan dalam pelatihan ini ada tiga model, yaitu model untuk lampion, lampu tidur gantung dan pot bunga. Model yang diberikan sengaja dibuat sederhana, karena tujuan awal dari pelatihan ini adalah untuk memotivasi siswa-siswi SMP 1 Kamang agar tertarik untuk membuat produk kreatif. Jika mereka diberikan model yang rumit, dikhawatirkan mereka akan merasa tidak mampu untuk melakukannya. Oleh sebab itu, model yang sederhana sangat penting diberikan di awal. Jika mereka sudah termotivasi, maka mereka bisa mengembangkan sesuai dengan kreativitas mereka sendiri.

\subsection{Presentasi Materi Pelatihan dan Teknik Pembuatan Produk.}

Tahan ini merupakan tahap pemberian materi pelatihan. Presentasi diawali dengan materi yang umum, yaitu materi tentang pentingnya menjaga lingkungan dari sampah plastik dan bahaya sampah plastik bagi lingkungan dan kesehatan manusia dan hewan. Kemudian dilajutkan dengan paparan tentang peluang-peluang industri kreatif dalam menyongsong revolusi industri 4.0. Selanjutnya paparan materi tentang pemanfaatan sampah plastik untuk membuat produk yang bernilai ekonomis. Kemudian dilanjutkan dengan paparan materi tentang alat, bahan dan teknik membuat lampion, lampu tidur gantung dan pot bunga dengan memanfaatkan sampah plastik. Paparan materi ini dilakukan dengan menggunakan metode ceramah dan dilanjutkan dengan diskusi atau tanya jawab. 


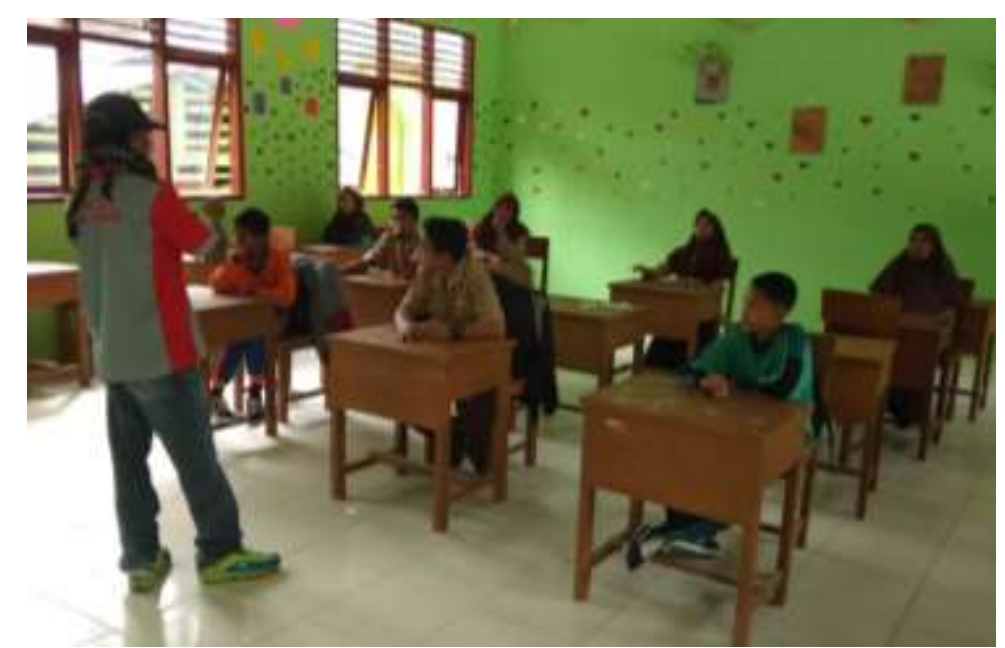

Gambar 1. Pemaparan materi pelatihan

\subsection{Proses Pembuatan Produk.}

Proses pembuatan produk adalah tahapan dimana materi pelatihan yang telah diberikan diimplementasikan dalam bentuk praktek. Proses pembuatan produk dibagi menjadi tiga sesi. Sesi pertama adalah sesi pembuatan lampion, sesi kedua adalah sesi pembuatan lampu tidur gantung, dan sesi ketiga adalah sesi pembuatan pot bunga. Berikut akan dijelaskan masing-masing sesi proses pembuatan produk.

\subsubsection{Sesi pembuatan lampion.}

Langkah pertama pembuatan lampion yaitu memotong pipa PVC sesuai ukuran model lampion yang telah disiapkan dengan menggunakan mesin gerinda tangan. Setelah itu pipa PVC digambar sesuai pola atau motif yang ada pada model lampion dengan menggunakan rol dan pensil atau spidol. Setelah itu pola atau motif dipotong dengan menggunakan mesin gerinda tangan atau mesin gerinda ukir. Kemudian pipa dilembekkan dengan menggunakan hair dryer galon 1500 watt. Setelah itu, pipa PVC yang telah lembek dilekuk atau dilengkungkan sesuai dengan model. Setelah selesai dilengkungkan, sisa pemotongan dibersihkan dengan menggunakan amplas. Setelah itu, pipa PVC tersebut diberi cat dasar dengan cat semprot warna abu-abu. Setelah kering, pipa yang telah diberi cat dasar diwarnai dengan teknik melukis ebru.

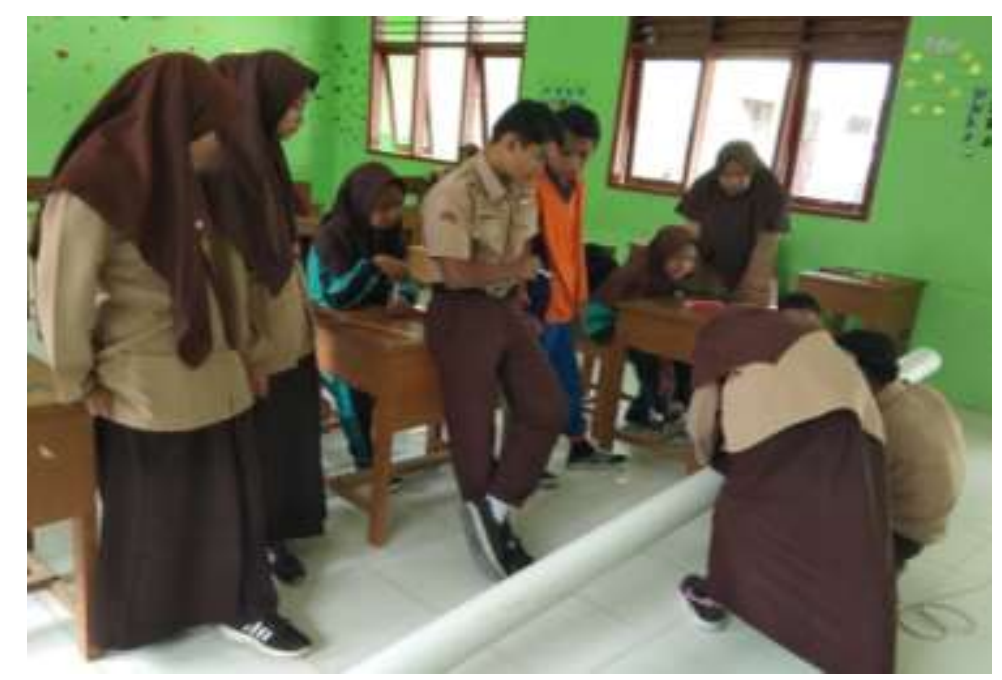

Gambar 2. Mengukur dan memotong pipa PVC 


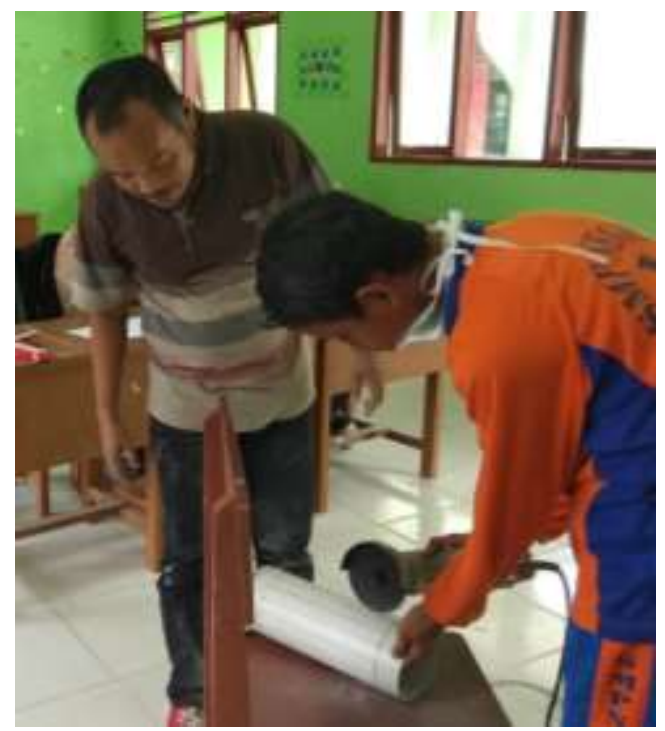

Gambar 3. Memotong pola/ motif

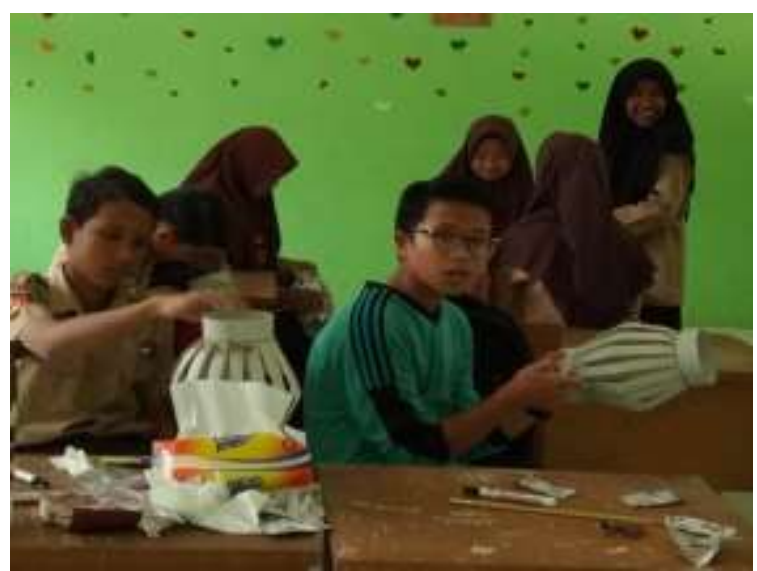

Gambar 4. Membentuk lengkungan lampion

Untuk mewarnai pipa dengan teknik melukis ebru, terlebih dahulu disiapkan baskom plastik yang diisi dengan air bersih. Setelah itu cat minyak kaleng dituang ke dalam baskom sesuai dengan warnawarni yang diinginkan. Sebelum cat kaleng dituangkan, aduk dulu cat kaleng sampai rata dengan tingkat kenceran sedang, jangan terlalu kental. Kalau terlalu kental, cat akan tebal sehingga hasilnya kurang bagus dan lama kering. Setelah cat dituang, cat diaduk sesuai bentuk yang diinginkan. Setelah itu, pipa PVC dicelupkan ke dalam baskom yang sudah dituang cat. Setelah cat menempel rata pada seluruh permukaan pipa PVC, maka PIPA PVC diangkat. Setelah itu pipa PVC dijemur atau dianginkan sampai cat benar-benar telah kering.

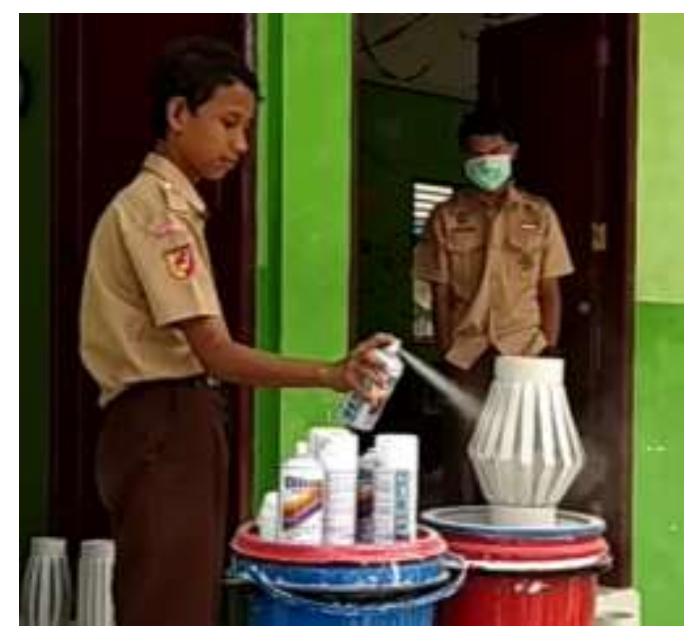

Gambar 5. Mencat dasar lampion 


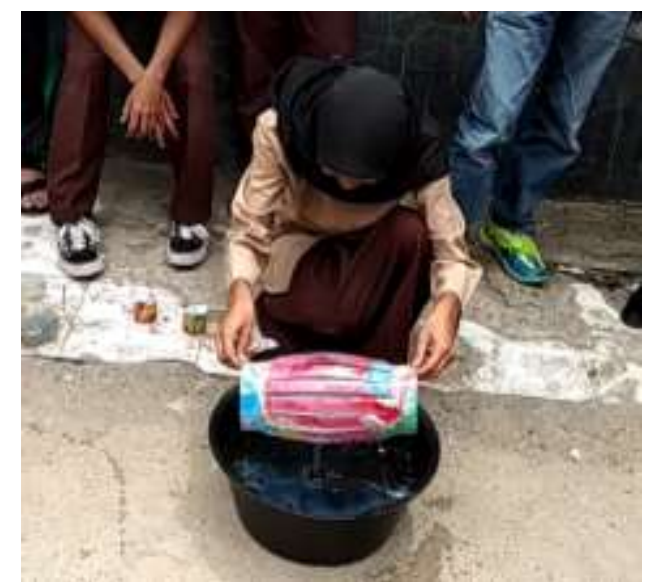

Gambar 6. Mewarnai lampion dengan teknik Ebru

Setelah proses pengeringan selesai, pipa PVC diberi fiber transparan pelapis pagar pada bagian dalam. Fiber transparan dipotong sesuai ukuran dan direkatkan dengan menggunakan lem tembak. Setelah pemasangan fiber transparan selesai, dipasang kedudukan lampu dengan menggunakan bahan pipa PVC yang telah dipotong sesuai ukuran dan didatarkan dengan menggunakn hair dryer galon. Pipa PVC yang telah didatarkan dilembekan dengan hair dryer galon dan dibengkokkan 90 derajat sesuai ukuran diameter pipa PVC. Setelah itu kedudukan lampu dipasang pada bagian atas pipa PVC. Pipa PVC dan kedudukan lampu dilobangi pada kedua sisinya dengan menggunakan solder listrik sesuai ukuran. Kemudian pipa PVC dan kedudukan lampu yang telah dilobangi dipasangi skrup. Pada bagian tengah kedudukan lampu dilobangi dengan menggunakan solder listrik atau gerinda ukir. Setelah itu kabel lampu dimasukkan melalui lobang tersebut. Pada ujung kabel bagian dalam dipasang fitting lampu dan pada bagian ujung sebelah luar dipasang cok lampu. Setelah selesai pemasangan lampu selesai, maka lampion difinishing dengan menggunakan pilox clear. Setelah itu, produk lampion selesai.

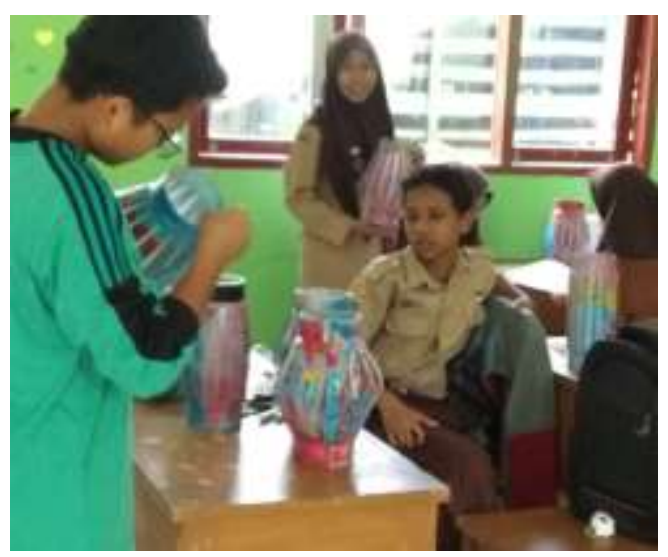

Gambar 7. Pemasangan fiber transparan

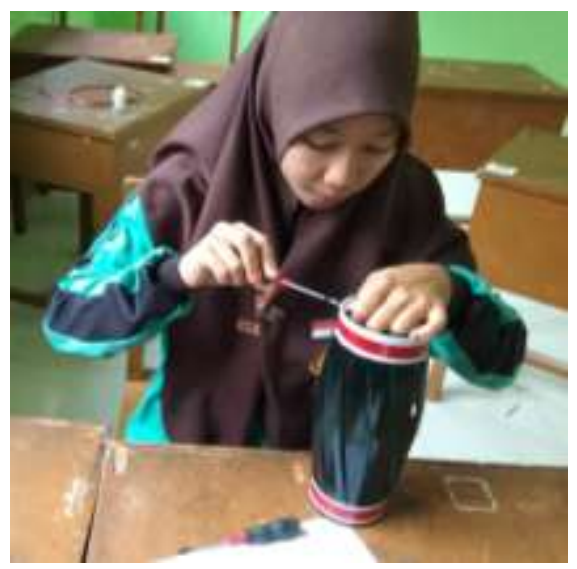

Gambar 8. Pemasangan kedudukan lampu 


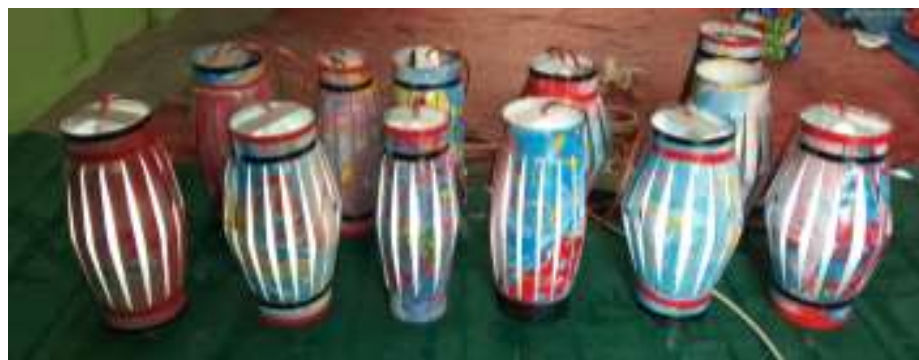

Gambar 9. Lampion telah selesai dipasang lampu

\subsubsection{Sesi pembuatan lampu tidur gantung}

Langkah pertama pembuatan lampu tidur gantung yaitu memotong pipa PVC sesuai ukuran model lampu tidur gantung yang telah disiapkan dengan menggunakan mesin gerinda tangan. Setelah itu pipa PVC digambar sesuai pola atau motif yang ada pada model lampu tidur gantung dengan menggunakan rol dan pensil atau spidol. Setelah itu pola atau motif dipotong dengan menggunakan mesin gerinda tangan atau mesin gerinda ukir. Setelah pola atau motif selesai dipotong, sisa pemotongan dibersihkan dengan menggunakan amplas. Setelah sisa pemotongan pola atau motif dibersihkan, maka pipa PVC tersebut diberi cat dasar dengan cat semprot warna abu-abu. Setelah kering, pipa yang telah diberi cat dasar diwarnai dengan cat semprot warna hitam. Setelah itu pipa PVC dikeringkan.

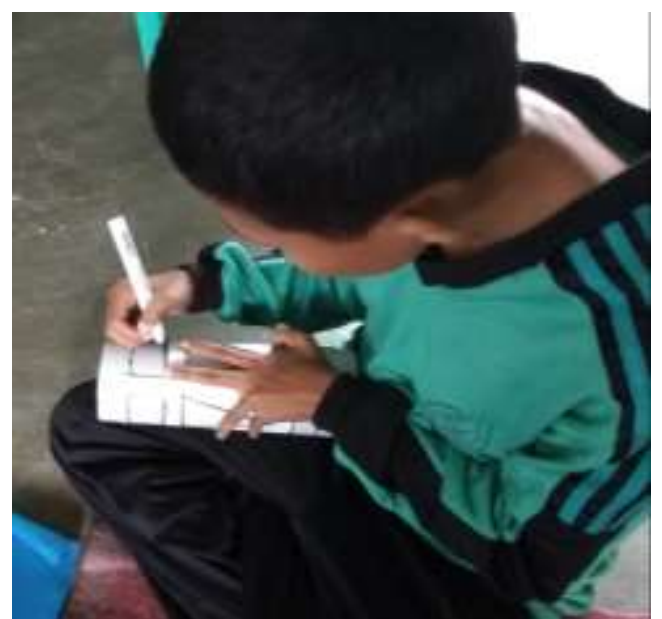

Gambar 10. Pembuatan pola/motif lampu tidur gantung

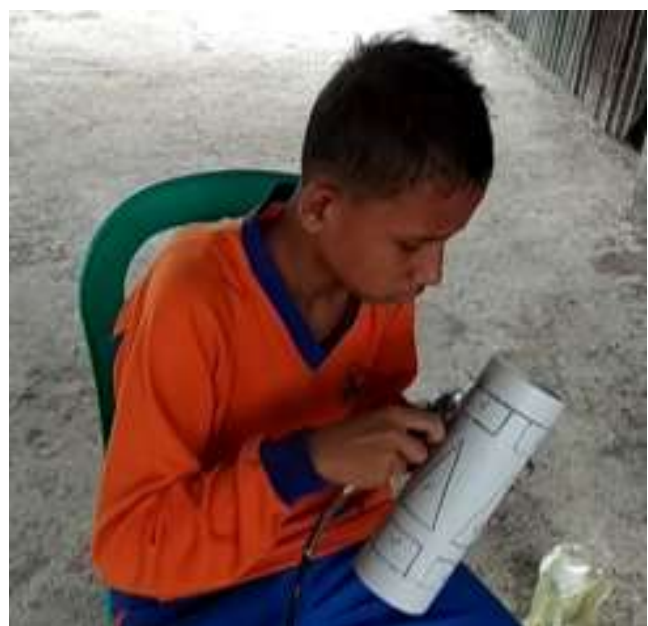

Gambar 11. Pemotongan pola/ motif lampu tidur gantung 


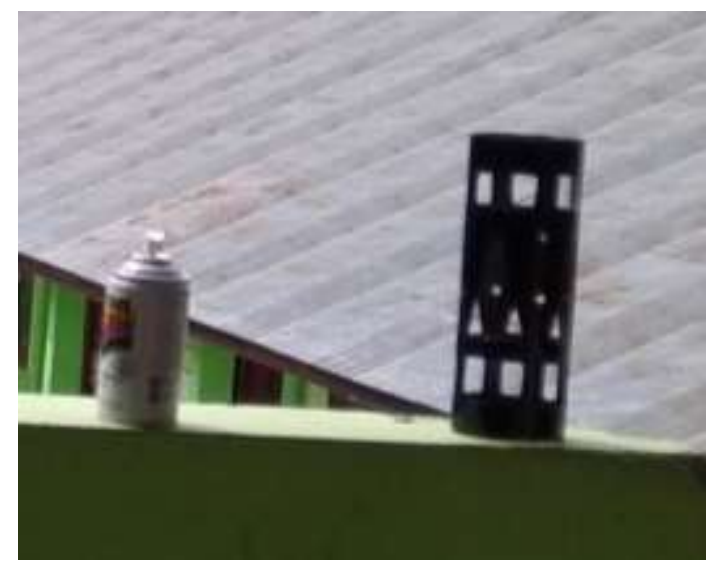

Gambar 12. Pewarnaan lampu tidur gantung dengan cat semprot warna hitam

Setelah proses pengeringan selesai, pipa PVC diberi fiber transparan pelapis pagar pada bagian dalam. Fiber transparan dipotong sesuai ukuran dan direkatkan dengan menggunakan lem tembak. Setelah pemasangan fiber transparan selesai, dipasang kedudukan lampu dengan menggunakan bahan pipa PVC yang telah dipotong sesuai ukuran dan didatarkan dengan menggunakn hair dryer galon. Pipa PVC yang telah didatarkan dilembekan dengan hair dryer galon dan dibengkokkan 90 derajat sesuai ukuran diameter pipa PVC. Setelah itu kedudukan lampu dipasang pada bagian atas pipa PVC. Pipa PVC dan kedudukan lampu dilobangi pada kedua sisinya dengan menggunakan solder listrik sesuai ukuran. Kemudian pipa PVC dan kedudukan lampu yang telah dilobangi dipasangi skrup. Pada bagian tengah kedudukan lampu dilobangi dengan menggunakan solder listrik atau gerinda ukir. Setelah itu kabel lampu dimasukkan melalui lobang tersebut. Pada ujung kabel bagian dalam dipasang fitting lampu dan pada bagian ujung sebelah luar dipasang cok lampu. Setelah pemasangan lampu selesai, maka lampu tidur gantung difinishing dengan menggunakan pilox clear. Setelah itu, produk lampu tidur gantung selesai.

\subsubsection{Sesi pembuatan pot bunga}

Langkah pertama pembuatan pot bunga yaitu memotong pipa PVC sesuai ukuran model pot bunga yang telah disiapkan dengan menggunakan mesin gerinda tangan. Sisa pemotongan dibersihkan dengan menggunakan amplas. Setelah pengamplasan selesai, bagian tengah agak ke bawah pipa PVC dilembekkan dengan menggunakan hair dryer galon. Setelah pipa PVC lembek, lalu pipa dipiuh/ dipelintir ke kiri 45-55 derajat. Setelah itu pipa dibiarkan dingin. Setelah pipa dingin, pada bagian tengah agak ke atas pipa PVC dipanaskan lagi dengan menggunakan hair dryer galon. Setelah pipa PVC lembek, pipa PVC dipiuh/ dipelintir ke kanan kira-kira 45-55 derajat. Pemiuhan ini akan membentuk draferi yang artistik. Setelah itu pipa didinginkan. Setelah pipa PVC dingin, maka pipa PVC diamplas sampai sisa pipa yang terbakar bersih. Untuk membuat efek-efek artistik, pipa dibakar dengan menggunakan gas torch. Setelah itu pipa dibersihkan lagi dengan menggunakan amplas. Kemudian pot bunga difinishing dengan menggunakan pilox clear. Setelah proses finishing selesai, pot bunga siap untuk digunakan.

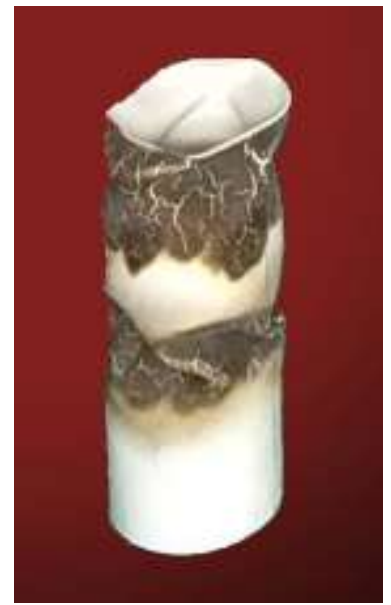

Gambar 13. Pot bunga yang telah difinishing 


\section{HASIL DAN PEMBAHASAN}

Pelatihan ini telah menghasilkan 3 macam prototipe produk industri kreatif dengan memanfaatkan sampah plastik pipa PVC. Produk yang dihasilkan yaitu lampion, lampu tidur gantung dan pot bunga. Produk tersebut dapat dilihat pada gambar berikut:

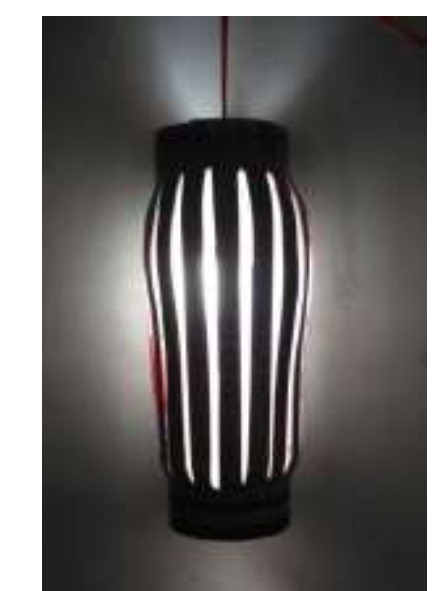

Gambar 14. Produk lampion

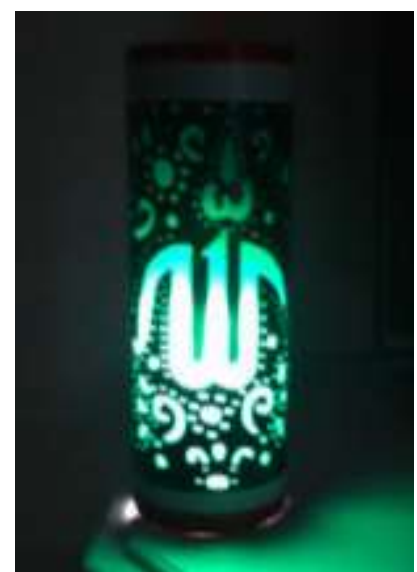

Gambar 15. Produk lampu tidur Gantung

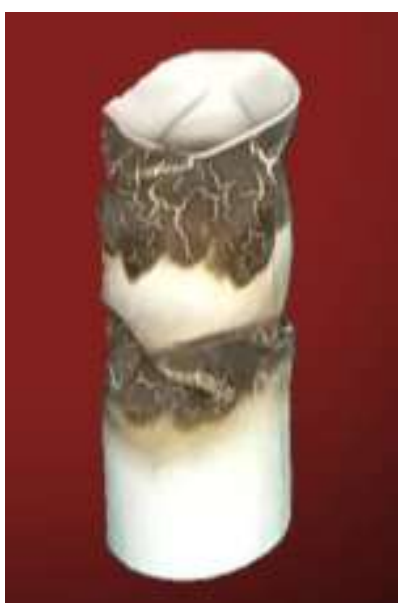

Gambar 16. Produk pot bunga

Produk yang telah dihasilkan dalam pelatihan ini memang belum sempurna. Hal ini disebabkan diantaranya karena peserta pelatihan baru pertama kali membuat produk seperti ini. Selain itu, peserta pelatihan sebelumnya belum pernah menggunakan alat-alat mesin yang digunakan untuk membuat produk dalam pelatihan ini. Oleh sebab itu, mereka masih canggung dan belum terbiasa 
dengan hal tersebut. Pelatihan ini merupakan hal baru bagi mereka. Namun demikian, motivasi dan antusia mereka cukup baik.

\section{KESIMPULAN}

Pelatihan pemanfaatan limbah plastik menjadi produk industri kreatif di SMP Negeri 1 Kamang Magek Kabupaten Agam Propinsi Sumatera Barat telah terselenggara dengan baik. Pelatihan ini telah diberikan kepada 15 orang peserta. Pelatihan ini dilakukan selama 16 kali tatap muka, dengan durasi satu kali tatap muka sama dengan dua jam. Selama 16 kali tatap muka tersebut, pelatihan ini dapat menghasilkan tiga produk industri kreatif dengan memanfaatkan limbah atau sampah plastik pipa PVC. Tiga produk yang telah dihasilkan adalah berupa lampion, lampu tidur gantung dan pot bunga.

\section{UCAPAN TERIMA KASIH}

Terselenggaranya pelatihan ini tidak terlepas dari dukungan dari berbagai pihak. Oleh sebab itu, Tim Pelaksana Pengabdian mengucapkan terima kasih kepada:

1. Prof. Novesar Jamarun, MS selaku Rektor ISI padangpanjang;

2. Dr. Yuniarti Munaf selaku Ketua LPPMPP ISI Padangpanjang beserta staf;

3. Drs. Desmawardi, M.hum selaku kepala pusat pengabdian ISI Padangpanjang;

4. Bapak Andri selaku Kepala SMP Negeri 1 Kamang Magek beserta staf;

5. Siswa-siswi SMP Negeri 1 Kamang Magek sebagai peserta pelatihan.

\section{DAFTAR PUSTAKA}

https://www.economist.com, 29 Maret 2019 pukul 11.55 WIB.

https://dosenbiologi.com/lingkungan/dampak-sampah-plastik, 29 Maret 2019 pukul 12.00 WIB. 